\title{
ABI1 wt Allele
}

National Cancer Institute

\section{Source}

National Cancer Institute. AB/1 wt Allele. NCI Thesaurus. Code C52438.

Human ABI1 wild-type allele is located in the vicinity of 10 p11.2 and is approximately 114 $\mathrm{kb}$ in length. This allele, which encodes abl interactor 1 protein, is involved in both cellular growth regulation and cytoskeletal organization. 